\title{
KESENIAN TARI DOLALAK SEBAGAI BRAND KABUPATEN PURWOREJO, JAWA TENGAH
}

\author{
Agus Budi Setyawan \\ Program Studi Desain Komunikasi Visual, Fakultas Desain dan Seni Kreatif \\ Universitas Mercu Buana Jakarta \\ budi.setyawan@mercubuana.ac.id
}

\begin{abstract}
ABSTRAK
Dolalak di Kabupaten Purworejo sebagai salah satu wujud dari seni tradisi kerakyatan, kehadirannya merupakan kelangsungan kehidupan kultural yang sudah berakar secara turun-temurun yang menjadi salah satu perwujudan budaya. Seiring perkembangannya, Dolalak dijadikan sebagai ikon kesenian untuk mendukung aktivitas branding pariwisata yang dilakukan oleh kabupaten Purworejo. Penelitian ini bertujuan untuk menjawab mengapa kabupaten Purworejo memilih Dolalak sebagai ikon keseniannya; upaya apa saja yang sudah dilakukan oleh kabupaten Purworejo dalam membangun brand Dolalak; serta bagaimana strategi pencitraan yang sudah dilakukan yang meliputi strategi visual dan strategi media. Penelitian ini menggunakan paradigma kualitatif dengan pendekatan etnografi, data penelitian didapatkan melalui wawancara dan observasi. Hasil penelitian mengungkap bahwa Dolalak dipilih sebagai ikon kesenian karena asli dari Purworejo, memiliki keunikan, eksis sampai saat ini, populer dan keberadaannya diterima oleh masyarakat Purworejo. Berbagai upaya telah dilakukan untuk membangun brand Dolalak, diantaranya dengan mementaskan Dolalak secara rutin dan mengirim Dolalak untuk mengikuti berbagai festival seni budaya di kabupaten/kota lain serta mengalihwahanakan Dolalak ke dalam berbagai media komunikasi visual. Melalui aktivitas branding yang dilakukan, Dolalak semakin dikenal oleh masyarakat, menguatkan positioning Kabupaten Purworejo, serta turut berperan dalam peningkatan kunjungan wisata di Purworejo.
\end{abstract}

Kata Kunci: Dolalak, Purworejo, Ikon Kesenian, brand, Branding. 


\section{PENDAHULUAN}

Dengan adanya otonomi daerah membuat kota maupun kabupaten di Indonesia saling berlomba untuk menarik wisatawan, investor, maupun pendatang. Pemerintah daerah di Indonesia, baik level provinsi, kabupaten, atau kota perlu melakukan city branding, agar tujuan tersebut dapat tercapai, daerahnya bisa semakin dikenal, sehingga diharapkan pertumbuhan ekonomi dan kesejahteraan masyarakatnya semakin meningkat. Pemerintah daerah harus membangun brand untuk daerahnya, tentu yang sesuai dengan potensi maupun positioning yang menjadi target daerah tersebut. Brand merupakan salah salah satu bagian terpenting dari suatu produk. City brand adalah indentitas, symbol, atau logo, yang melekat pada suatu daerah. City brand dapat dikatakan sebagai sekelompok keyakinan yang disodorkan oleh suatu kota dan diterima oleh masyarakatnya. Branding sendiri adalah proses komunikasi dan aktivitas yang dijalankan untuk membuat brand semakin besar dan bersinar (Susanto\&Wijanarko, 2004:15).

Kabupaten Purworejo secara geografis berada pada 109o 47' 28" sampai dengan 110o 08' 20" Bujur Timur dan 7o 32' sampai dengan 7o 54' Lintang Selatan, dengan luas wilayah $1.034,81752 \mathrm{~km}^{2}$. Batas wilayah di sisi utara yang berbatasan dengan Kabupaten Magelang dan Wonosobo, disebelah timur berbatasan dengan Daerah Istimewa Yogyakarta, disisi barat berbatasan dengan Kabupaten Kebumen dan sebelah selatan Samudera Indonesia. Posisi kabupaten Purworejo sangat strategis karena dilewati jalur nasional dan dekat dengan kota-kota lain yang sudah terkenal seperti Magelang dengan Candi Borobudurnya dan Yogyakarta dengan berbagai pariwisatanya. Namun yang disayangkan, Purworejo hanya dijadikan tempat perlintasan semata saat wisatawan berkunjung ke kota-kota tersebut. Tidak ingin hanya sekedar mendapatkan "asap kendaraan" maka Purworejo mencoba menjajakan kotanya agar menjadi tempat destinasi, atau minimal kota transit sebelum wisatawan mengunjungi tempat lain. Untuk mencapai tujuan tersebut pemerintah daerah kabupaten Purworejo membangun brand untuk daerahnya dengan menggali potensi unik yang dapat ditonjolkan Purworejo dari sektor kesenian tradisinya. Di wilayah kabupaten Purworejo tumbuh dan berkembang jenis-jenis kesenian tradisi rakyat, seperti: Selawatan, Kuntulan, Madyapitutur, Kuda Kepang, Samanan, Kobrasiswa, dan Dolalak. Dari sekian jenis seni rakyat, Dolalak dipilih sebagai ikon kesenian dan dipergunakan untuk mendukung aktivitas branding dari kabupaten Purworejo.

Bentuk kesenian Dolalak merupakan perpaduan tari, musik dan lagu vokal (koor) sedangkan isi yang dituangkan dalam garapan tari mengandung nilai kehidupan kebersamaan atau gotong-royong, menggambarkan sikap kegagahan, disiplin sekaligus suasana kegembiraan. Mengacu pada Laporan Proyek Pembina Kesenian Jawa Tengah tahun 1992/1993 dengan judul Deskripsi Kesenian Dolalak, nama tari Dolalak berasal dari kata "do" dan "la-la" yaitu ucapan notasi lagu diatonis yang dinyanyikan oleh serdadu-serdadu Belanda dalam tangsi untuk mengiringi atau dinyanyikan sambil menari-nari. Ucapan do la la yaitu notasi lagu $1-6-6$, oleh masyarakat Purworejo yang dekat dengan tangsi ditirukan menjadi Ndolalak (lidah Jawa), termasuk juga meniru gerak-gerak serdadu-serdadu Belanda dan bentuk/motif yang diterapkan pada busananya. 
Busana penari Dolalak sepintas mirip pakaian prajurit Belanda. Busana bagian atas berupa baju lengan panjang dan bagian bawah celana pendek dengan warna dasar hitam, menggunakan rumbai-rumbai pada kedua sisi pundaknya, geblekan pada bagian dada dan punggung, menggunakan motif untu walang pada bagian ujungnya (untuk menunjukkan kewibawaan) dengan kombinasi motif kembang teki. Penutup kepala menggunakan topi pet berwarna hitam dengan hiasan berbentuk bintang dengan kacamata hitam sebagai penutup mata. Sampur diikatkan pada bagian pinggang sebelah kiri, menggunakan kaos kaki setinggi betis sebagai alas kakinya. Rias pada penari Dolalak adalah rias sederhana pada bagian wajah, paling dominan menggunakan bedak dan pemerah pipi (Prihatini, 2000: 82-90).

Dolalak menjadi kesenian komunal yang berkembang di wilayah kabupaten Purworejo. Berdasarkan data base bidang kebudayaan dari Dinas Pendidikan Kebudayaan Pemuda dan Olahraga, Kabupaten Purworejo tahun 2015, tercatat ada sebanyak 50 lebih kelompok kesenian Dolalak yang ada dan tersebar di wilayah kabupaten Purworejo. Persebaran kesenian Dolalak di wilayah Purworejo melahirkan keberagaman penggayaan pada tari Dolalak, diantaranya adalah gaya Kaligesingan, Mlaranan dan Pesisiran. Kecintaan masyarakat Purworejo terhadap kesenian Dolalak diwadahi dalam suatu komunitas yang dibentuk melalui sosial media facebook, dengan nama komunitas Ndolalak Fans Club (NFC). Sampai saat ini jumlah anggota NFC tercatat sebanyak 10.600 lebih orang, komunitas ini digunakan sebagai ajang diskusi dan berbagi informasi seputar kesenian Dolalak, seperti halnya informasi terkait dengan jadwal dan lokasi pementasan kesenian Dolalak.
Seiring perkembangannya, kesenian Dolalak tidak hanya sebagai seni pertunjukan rakyat yang berfungsi sebagai hiburan semata, akan tetapi keberadaannya saat ini sebagai aset budaya unggulan yang dijadikan sebagai brand dan dimanfaatkan untuk membangun citra kabupaten Purworejo, yang diantaranya dilakukan melalui alih wahana dari Dolalak sebagai seni pertunjukan ke dalam berbagai media komunikasi visual baik cetak maupun elektronik, produk-produk souvenir dan lain sebagainya sehingga memberikan nilai tambah bagi masyarakat secara ekonomi, menjadikan kebanggaan tersendiri bagi masyarakat pendukungnya serta memperkuat brand Dolalak kabupaten Purworejo. Penggunaan Dolalak sebagai brand Purworejo turut memberikan dampak yang positif bagi pertumbuhan pariwisata di Purworejo. Berdasarkan data yang diperoleh dari dinas Pariwisata dan Kebudayaan Kabupaten Purworejo, tercatat jumlah kunjungan wisatawan di Purworejo mengalami peningkatan dari tahun ke tahun. Sewaktu sebelum dilakukan branding pada tahun 2013 jumlah kunjungan wisatawan sebanyak 152.370 pengunjung, setelah dilakukan branding jumlah kunjungan wisatawan mengalami peningkatan, pada tahun 2014 meningkat menjadi 206.623 pengunjung, tahun 2015 mengalami peningkatan menjadi 478.176 pengunjung dan pada tahun 2016 mengalami peningkatan yang signifikan menjadi 855.964 pengunjung.

\section{PERMASALAHAN}

Tari Dolalak di Kabupaten Purworejo sebagai salah satu wujud dari seni tradisi kerakyatan, kehadirannya merupakan kelangsungan kehidupan kultural yang sudah berakar secara turun-temurun yang menjadi salah satu perwujudan budaya. 
Sebagai bentuk kesenian tari maka Dolalak mengutamakan unsur gerak yang dipadukan dengan ragam motif busana guna menunjang tampilan visualnya untuk mendapatkan daya hibur secara maksimal kepada penonton. Dalam upaya mengalih wahanakan gerak tari yang dinamis menjadi unsur dan prinsip dalam proses branding kota maka diperlukan atensi dan perlakuan yang memang berbeda agar nilai yang ingin diwujudkan tidak melenceng. Sehingga bisa dirumuskan permasalahan dalam penelitian ini adalah: Bagaimana bentuk dan konsep bentuk branding kabupaten Purworejo?

\section{TUJUAN PENELITIAN}

Tujuan dari penelitian ini adalah untuk mengungkap mengapa kabupaten Purworejo memilih Dolalak sebagai ikon keseniannya; untuk mengetahui berbagai upaya yang sudah dilakukan oleh kabupaten Purworejo dalam membangun brand Dolalak; serta untuk mengetahui bagaimana strategi pencitraan yang sudah dilakukan yang meliputi strategi visual dan strategi media. Hasil penelitian ini diharapkan dapat dijadikan sebagai rujukan ataupun pertimbangan bagi kabupaten/kota lain yang ingin melakukan branding kota dengan berbasis ide pada seni tradisi.

\section{METODOLOGI}

Penelitian ini menggunakan paradigma kualitatif dengan pendekatan etnografi. Kegiatan penelitian ini meliputi pengumpulan data, analisis data, interprestasi data, dan pada akhirnya dirumuskan suatu kesimpulan yang mengacu pada analisis data tersebut. Data penelitian didapatkan melalui dua cara, yaitu: wawancara dan observasi. Wawancara dilakukan dengan memilih narasumber yang terlibat secara langsung dengan aktivitas brand Dolalak, yang berasal dari pihak pemerintah daerah Purworejo selaku pemangku kepentingan dan kebijakan, serta masyarakat pendukung Dolalak. Observasi dilakukan dengan cara mengamati berbagai transformasi bentukan Dolalak yang ada di Purworejo, seperti apa setrategi kreatifnya dan perwujudan visual yang diaplikasikan ke dalam berbagai media komunikasi visual dan produk souvenir. Dalam observasi, peneliti melakukan pengambilan gambar baik berupa fotografi maupun audio visual sehingga dapat merekam hal-hal yang penting dalam penelitian. Analisis data penelitian dilakukan dengan mempelajari seluruh data-data yang didapatkan, setelah itu melakukan reduksi data dengan membuat rangkuman inti, langkah selanjutnya menyusun dalam satuan-satuan yang kemudian dikategorikan dalam satu kelompok yang sama, kemudian dilakukan pemeriksaan keabsahan data dan tahap yang terakhir disimpulkan.

\section{ANALISIS}

Mengacu pada Laporan Proyek Pembina Kesenian Jawa Tengah tahun 1992/1993 dengan judul Deskripsi Kesenian Dolalak, asal mula kesenian Dolalak adalah akulturasi budaya Eropa (Belanda) dengan Jawa yang terjadi di Kabupaten Purworejo, Jawa Tengah. Pada zaman Hindia Belanda, wilayah Purworejo terkenal sebagai daerah/tempat pelatihan serdadu/tentara yang berasal dari berbagai daerah oleh militer Belanda. Selama pelatihan mereka hidup di dalam tangsi/barak tentara, maka untuk membuang kebosanan mereka menari dan menyanyi. Gerakan dan lagu yang menarik kemudian menjadi inspirasi pengembangan kesenian yang sudah ada yaitu rebana (kemprang) dari tiga orang pemuda dari 
dukuh Sejiwan Desa Trirejo, Kecamatan Loano yaitu: Rejotaruno, Duliyat dan Ronodimejo. Sekitar tahun 1915, Ketiga orang tersebut bersama dengan warga masyarakat yang pernah menjadi serdadu Belanda membentuk kelompok kesenian. Menurut Untariningsih (56 tahun), pada awalnya pertunjukan kesenian tidak diiringi instrumen, namun dengan lagu-lagu vokal yang dinyanyikan silih berganti oleh para penari atau secara koor. Perkembangan berikutnya setelah dikenal dan digemari oleh masyarakat, pertunjukan kesenian ini diberi instrumen/iringan dengan lagu-lagu tangsi yang terasa dominan dengan notasi do-la-la. Dalam proses perkembangannya dari pengaruh zaman dan kondisi kemasyarakatan serta penyajiannya maka kesenian ini kemudian menjadi Dolalak.

Menurut Jono (54 th) kesenian Dolalak memiliki keunikan pada gerakan tariannya, karena merupakan perpaduan antara gerakan tari Jawa, pencak silat, baris berbaris dan dansa. Pada awal kemunculannya Dolalak hanya ditarikan oleh kaum pria dan masih terbatas pada wilayah tertentu saja. Pada masa itu ada anggapan tabu dari masyarakat apabila kaum perempuan tampil di depan umum. Sejak tahun 1976, pertunjukan kesenian Dolalak mulai ditarikan oleh kaum perempuan dan hal ini mendapat sambutan yang luar biasa dari masyarakat Purworejo.

\section{Dolalak Sebagai Ikon Kesenian Kabupaten Purworejo}

Dari sekian jenis seni rakyat yang ada di Purworejo, Dolalak merupakan salah satu yang paling banyak penggemar dan masih hidup bertahan sampai saat ini. Kesenian Dolalak tumbuh subur di wilayah pedesaan di kabupaten Purworejo, para pelaku (penari) kesenian Dolalak rata-rata merupakan remaja putri yang masih berstatus sebagai pelajar. Mereka yang tergabung dalam kelompok kesenian Dolalak pada umumnya ingin menyalurkan bakat dan minatnya pada bidang seni serta sebagai bentuk ungkapan rasa kekeluargaan.

Lebih lanjut menurut Untariningsih, eksistensi kesenian Dolalak di Purworejo sampai saat ini tak lepas dari kecintaan dan adanya rasa memiliki dari masyarakat, terutama generasi muda terhadap Dolalak yang hampir merata di wilayah kabupaten Purworejo. Kesenian Dolalak sering dipentaskan di berbagai acara, seperti pada perayaan hari besar nasional hingga acara hajatan perkawinan dan lain sebagainya. Setiap pementasan Dolalak selalu ramai dipenuhi oleh penonton yang sebagian besar dari kalangan muda, terlebih jika yang tampil adalah kelompok Dolalak idola mereka. Keramaian penonton selanjutnya dimanfaatkan oleh pedagang tradisional untuk menggelar barang dagangannya. Berdasarkan fakta seni yang berkembang di masyarakat tersebut, selanjutnya Dolalak ditetapkan sebagai ikon kesenian kabupaten Purworejo dan dijadikan sebagai duta seni untuk mewakili kabupaten Purworejo melalui pementasan kesenian yang ditampilkan di dalam maupun di luar wilayah kabupaten Purworejo.

Menurut Bambang Jati (55 tahun), keberadaan Dolalak sebagai ikon kesenian Purworejo menjadi aset kebudayaan yang kemudian dimanfaatkan keberadaannya untuk mendukung aktivitas pencitraan dari kabupaten Purworejo yang diwujudkan ke dalam berbagai bentuk dan tampilan pada berbagai media komunikasi visual.

Berdasarkan penjelasan dari para narasumber di atas, diketahui bahwa dasar 
pemilihan Dolalak sebagai ikon kesenian kabupaten dapat dilihat dalam diagram berikut:

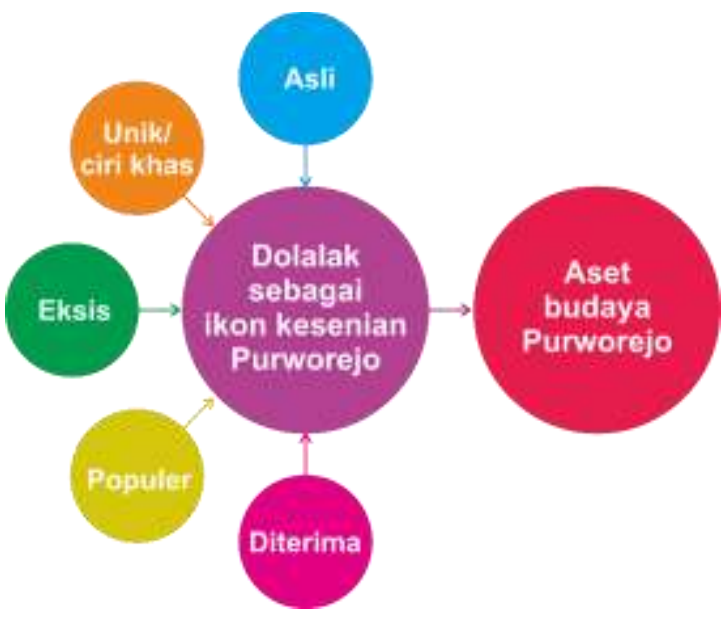

Gambar 1. Diagram dasar pemilihan tari Dolalak sebagai ikon kesenian kabupaten Purworejo. Sumber gambar: Agus Budi setyawan, 2016.

\section{Upaya kabupaten Purworejo dalam membangun Brand Dolalak}

Pemerintah Daerah Purworejo menaruh perhatian terhadap kesenian Dolalak dengan sering mementaskan Dolalak pada perayaan-perayaan hari besar nasional, seperti hari kemerdekaan Republik Indonesia, hari pendidikan nasional, perayaan malam tahun baru dan juga pada hari besar agama, seperti Idul Fitri. Dolalak juga sering dipentaskan pada acara peresmian-peresmian yang dilakukan oleh pemerintah daerah. Selain itu, Dolalak rutin mengisi pentas seni daerah yang diselenggarakan setiap malam minggu kedua dan ke-empat bertempat di gedung kesenian Sarwo Edhie Wibowo, Purworejo. Untuk memperkenalkan Dolalak pada masyarakat diluar daerah Purworejo, Dolalak ditampilkan pada acara-acara penyambutan tamu daerah; Dolalak sebagai duta Purworejo untuk mengikuti eventevent kesenian yang diadakan di kota-kota lain; juga mengenalkan Dolalak melalui media massa baik cetak maupun elektronik.
Pada tahun 2009 Departemen Pendidikan dan Kebudayaan Kabupaten Purworejo bekerja sama dengan sanggar tari 'Prigel' membuat modul dan CD pembelajaran Dolalak yang dijadikan sebagai pegangan dalam pelatihan Dolalak yang diikuti sekitar 150 guru-guru kesenian tingkat SD hingga SMA di Kabupaten Purworejo. Selanjutnya, modul tersebut didistribusikan ke sekolah-sekolah untuk dijadikan sebagai modul pengajaran Dolalak. Puncaknya pada perayaan hari pendidikan nasional pada tahun 2009 tingkat kabupaten Purworejo, momentum ini dimanfaatkan sebagai media ekspresi dan apresiasi seni pelajar dengan menggelar pementasan Dolalak masal yang diselenggarakan di alun-alun kabupaten Purworejo. Kegiatan tersebut diikuti sebanyak 1.683 pelajar dari tingkat Sekolah Dasar (SD)/MI, SLTP/MTS dan SLTA/SMK/MA yang ada di wilayah Kabupaten Purworejo.

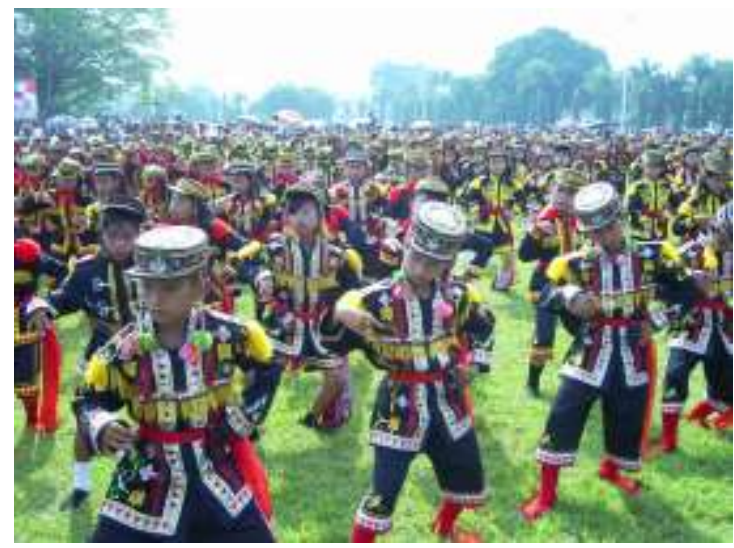

Gambar 2. Tari Dolalak masal yang diselenggarakan di alun-alun Kabupaten Purworejo Sumber Foto: Agung Pranoto, 2009

Sebagai bentuk perhatian dan perlindungan terhadap kesenian Dolalak, pemerintah daerah Kabupaten Purworejo mendaftarkan hak paten Dolalak supaya tidak diklaim oleh pihak lain. Pada tanggal 28 Februari 2011, Dolalak Purworejo resmi terdaftar hak patennya dengan nomor 049926 atas nama Pemerintah Daerah 
Kabupaten Purworejo sebagai pemegang hak paten tersebut.

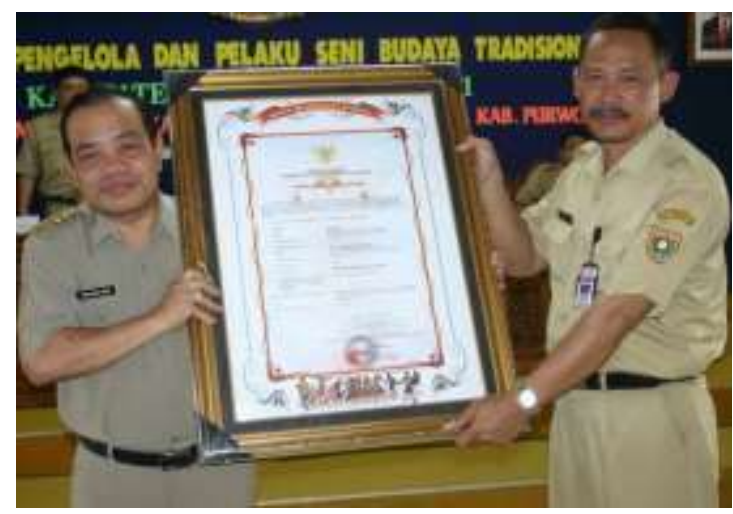

Gambar 3. Bupati Purworejo (sebelah kiri) beserta Sekda Purworejo (sebelah kanan) menunjukkan Piagam HAKI Dolalak Purworejo Foto: Agung Pranoto, 2011

Pada tahun 2012 pemerintah daerah Kabupaten Purworejo melalui Dinas Koperasi Perindustrian Perdagangan dan Pariwisata mengukuhkan Desa Kaliharjo, Kecamatan Kaligesing, Kabupaten Purworejo sebagai Desa Wisata Seni Budaya Dolalak, Hal tersebut berdasarkan pertimbangan bahwa kesenian Dolalak di Desa Kaliharjo masih asli. Di desa Kaliharjo terdapat kelompok Dolalak pria dan wanita dengan anggota kelompok lebih dari 50 orang penari mulai dari usia anak-anak, remaja hingga dewasa (sudah berkeluarga). Pemuda/i karang tarunanya juga turut mendukung keberlangsungan Dolalak dengan membentuk kelompok Dolalak sendiri. Desa wisata seni Dolalak Kaliharjo terintegrasi dengan desa-desa wisata lain yang ada di Kecamatan Kaligesing seperti Desa Sumongari, Kaligono, dan Donorejo dengan wisata alamnya berupa air terjun dan goa. Kegiatan Desa Wisata Kaliharjo membangun mutu tari organisasi, menempatkan lokasi pementasan yang jelas, menyajikan pertunjukan dan paket pelatihan menari Dolalak untuk wisatawan yang berkunjung.
Pada tanggal 5 Januari 2013, pemerintah daerah Kabupaten Purworejo meresmikan logo branding kotanya. Atribut kesenian Dolalak (topi penari Dolalak) dijadikan sebagai elemen pembentuk pada visualisasi logo branding Purworejo. Selanjutnya logo branding tersebut diaplikasikan kedalam berbagai media komunikasi visual sebagai identitas dari kabupaten Purworejo.
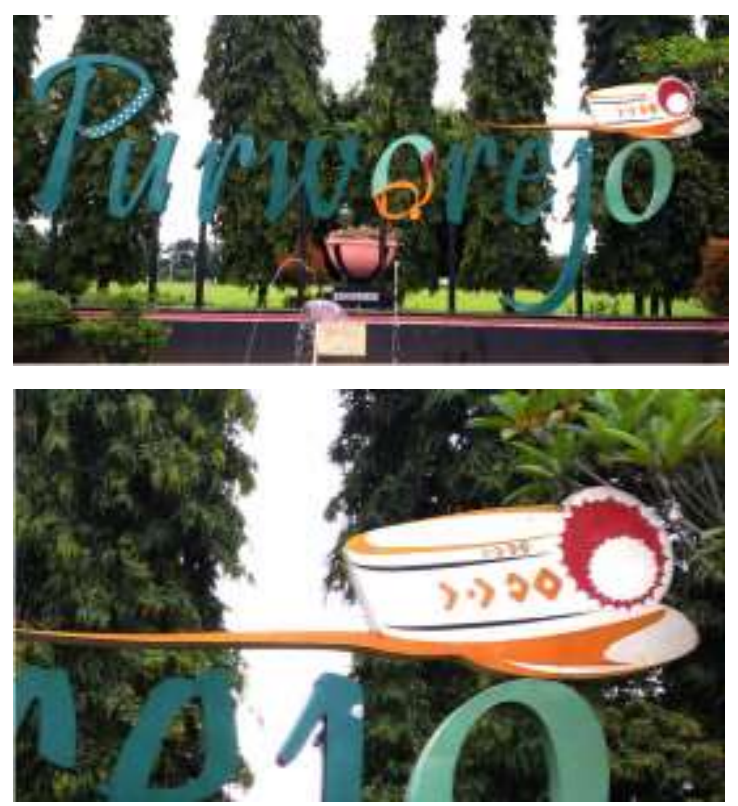

Gambar 4. Logo branding kabupaten Purworejo Foto: Agus Budi Setyawan, 2016

Upaya lain yang dilakukan oleh pemerintah daerah kabupaten Purworejo dalam membangun brand Dolalak adalah dengan membuat patung penari Dolalak dalam ukuran yang relatif besar dan ditempatkan di halaman gedung kesenian Sarwo Edhie Wibowo, Purworejo. Hal tersebut bertujuan untuk menunjukkan eksistensi kesenian Dolalak di kabupaten Purworejo. Patung penari Dolalak ini mengambil figur penggambaran seorang penari putri dengan gerakan salam pembuka yang kemungkinan bentuk ini dipilih berdasarkan animo masyarakat serta menunjukkan proses perkembangan eksistensi tari tersebut. 


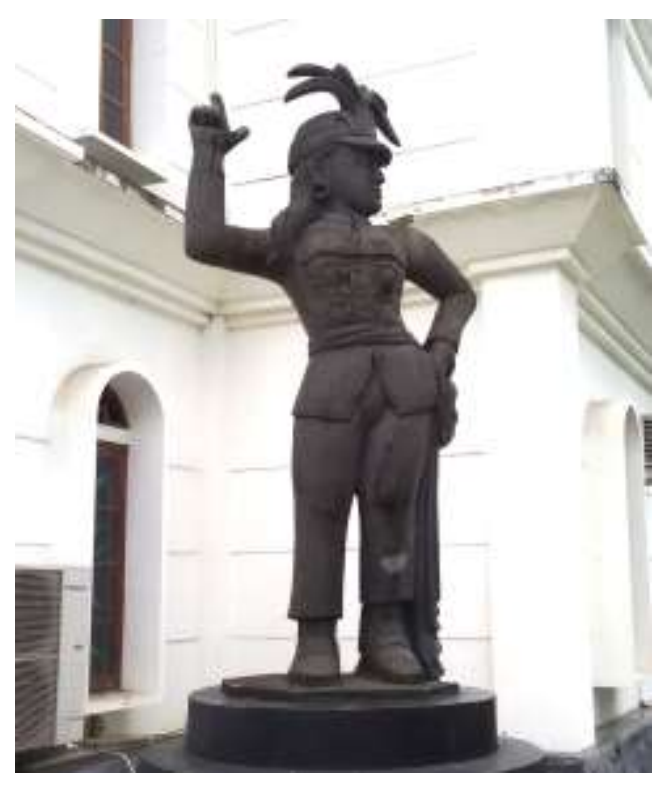

Gambar 5. Patung Dolalak Putri Foto: Agus Budi Setyawan, 2016

Pada tanggal 11 Desember 2016, kesenian Dolalak ditunjuk untuk mewakili kabupaten Purworejo pada acara festival Tidar 2016 yang diselenggarakan di kabupaten Magelang, Jawa Tengah. Pada acara tersebut kontingen kesenian Dolalak Purworejo meraih juara 3 dari 27 kabupaten lain yang turut serta. Menariknya komposisi penari Dolalak yang tampil merupakan gabungan antara penari Dolalak asli dan pesonil TNI dari kodim 412 Purworejo.

\section{Strategi Branding Dolalak kabupaten Purworejo}

Untuk menciptakan citra brand yang positif dapat melalui program pemasaran yang menghubungkan asosiasi yang kuat, menguntungkan, dan unik untuk menanamkan brand dalam memori target sasaran. Asosiasi brand merupakan simpul informasi yang terkait brand dalam memori serta meliputi makna brand bagi konsumen/target sasarannya. Asosiasi tersebut datang dalam berbagai bentuk serta merefleksikan karakteristik produk (Swasty, 2016:113).
Diperlukan strategi kreatif sebagai langkah untuk mencapai tujuan pencitraan Dolalak Purworejo. Adapun strategi kreatif yang sudah dilakukan dalam aktivitas pencitraan Dolalak yakni melalui pementasan yang rutin diadakan digedung kesenian Sarwo Edhie Wibowo, mengikut sertakan Dolalak Purworejo dalam berbagai event/festival seni budaya yang digelar di kabupaten atau kota lain, memberikan pembinaan kepada kelompok kesenian Dolalak yang ada di pedesaan, memberikan pelatihan kepada guru-guru kesenian, membuat materi pembelajaran seni tradisi Dolalak sebagai muatan lokal serta mempublikasikan dokumentasi kegiatan dan informasi terkait dengan Dolalak Purworejo melalui halaman situs resmi kabupaten Purworejo.
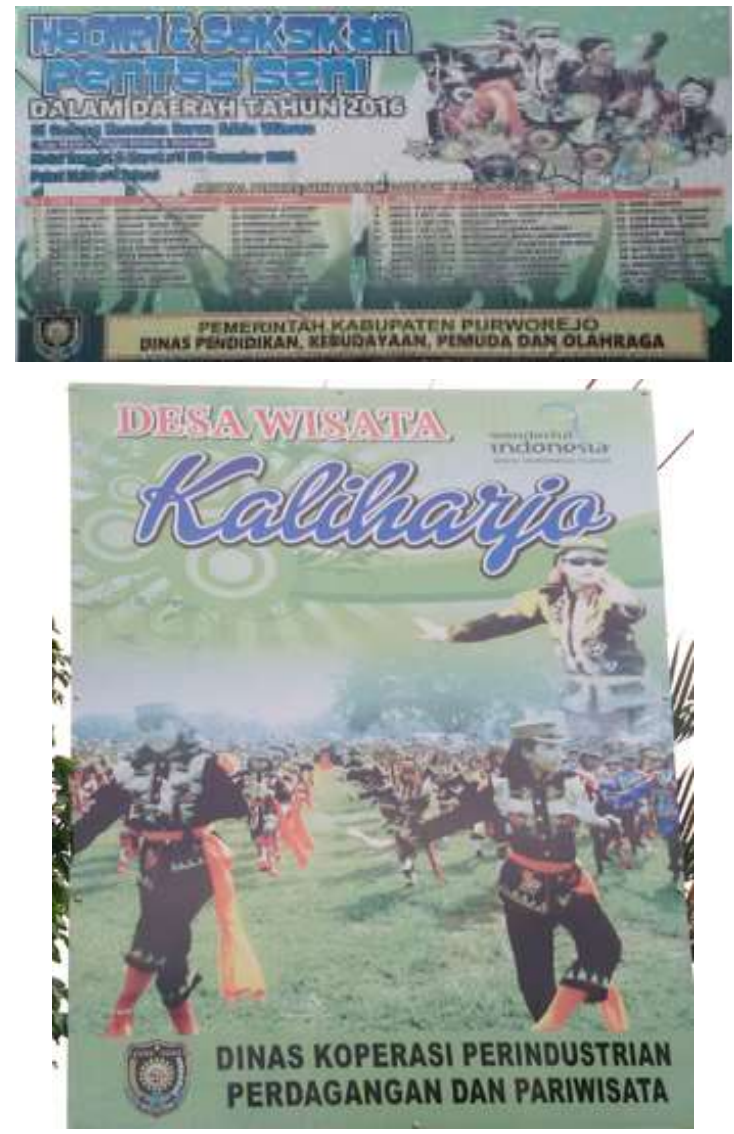

Gambar 6. Visualisasi Dolalak dalam media komunikasi visual

Dokumentasi oleh Agus Budi Setyawan, 2016 


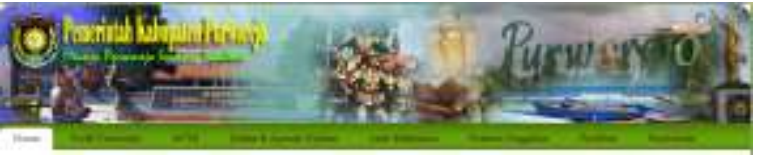

Gambar 7. Visualisasi Dolalak dalam media banner website kabupaten Purworejo http://purworejokab.go.id/ akses 2016

Visual tidak hanya perhatian dengan bagaimana gambar itu tampak, tetapi bagaimana gambar-gambar dilihat. Apa yang menjadi penting tentang gambargambar tersebut bukan gambar itu sendiri, melainkan bagaimana gambar itu diihat oleh penonton tertentu yang melihat dengan cara tertentu pula (Rose dalam Ida, 2014:1280). Visual merupakan aspek penting dalam mendukung aktivitas pencitraan kesenian Dolalak Purworejo. Diperlukan strategi visual yang tepat sehingga pesan komunikasi visualnya dapat tersampaikan dengan baik. Strategi visual yang digunakan dalam pencitraan kesenian Dolalak dibuat dengan menggunakan pendekatan tone \& manner kemeriahan festival. Tone \& manner merupakan suatu gaya pendekatan dalam berkomunikasi. Ini erat berhubungan dengan kepribadian brand, serta memiliki fungsi memperkuat ekspresi ide (Kasilo, 2008:63).

Kemeriahan festival divisualisasikan dengan menampilkan sosok penari Dolalak putri dengan busana dan atribut lengkap sedang beraksi memperlihatkan komposisi dan kelincahan gerakan tari Dolalak. Background penari Dolalak dibuat dominan menggunakan warna dasar hijau dengan penambahan sorotan cahaya dan kemerlip bintang. Visualisasi dibuat dengan komposisi seimbang dan visualisasi penari Dolalak dijadikan sebagai penekanannya. Pesan komunikasi dituliskan menggunakan tipografi dengan karakter yang dinamis, hal ini mengacu pada karakter gerakan penari Dolalak yang lincah.
Media komunikasi visual sangat berperan penting dalam aktivitas pencitraan kesenian Dolalak Purworejo. Melalui media pesan komunikasi disampaikan kepada khalayak, ketepatan pemilihan media berpengaruh terhadap ketersampaian pesan komunikasi tersebut. Kadang ada suatu media yang tidak begitu kuat saat berdiri sendiri, tetapi ketika dipandang secara integral media tersebut sangat memperkuat media-media lainnya. Bukan sekedar memunculkan sebanyakbanyaknya media, akan tetapi media-media tersebut harus sinergi satu dengan yang lainnya. Agar bisa melakukan hal yang integral, maka harus memahami karakteristik media yang akan digunakan serta bagaimana khalayak yang dituju berinteraksi dengan media-media tersebut (Kasilo, 2008:83).

Strategi media yang digunakan dalam pencitraan kesenian Dolalak menitik beratkan pada aspek efektif dan efisien. Efektif dimaksudkan adalah media komunikasi visual yang digunakan dapat menjangkau khalayak yang luas, sedangkan efisien adalah dari segi pembiayaan yang tidak terlalu mahal. Media komunikasi visual yang digunakan untuk aktivitas pencitraan kesenian Dolalak Purworejo meliputi: baligho, backdrop, sticker, produk souvenir, banner website dan sosial media

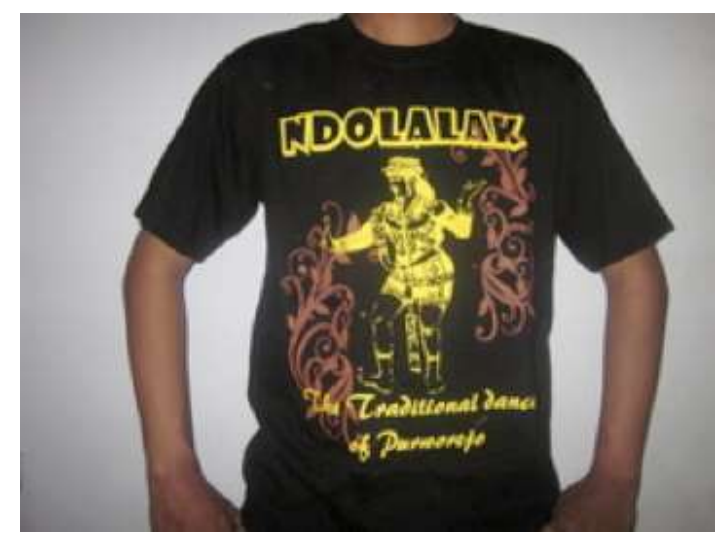

Gambar 8. Kaos dengan desain Dolalak 


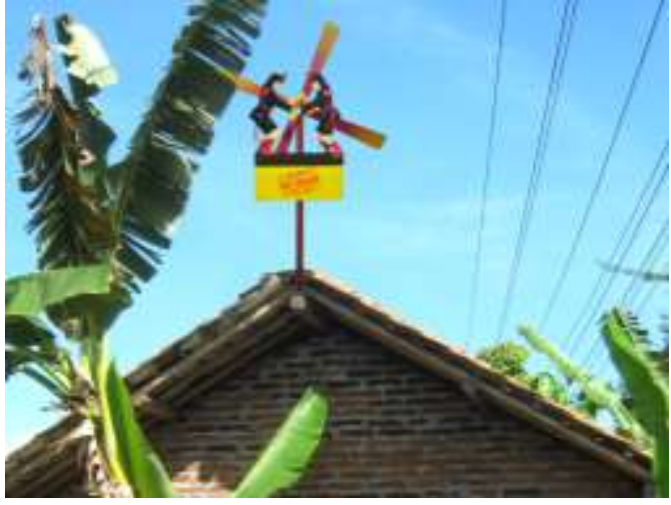

Gambar 9. Kitiran dengan karakter penari Dolalak

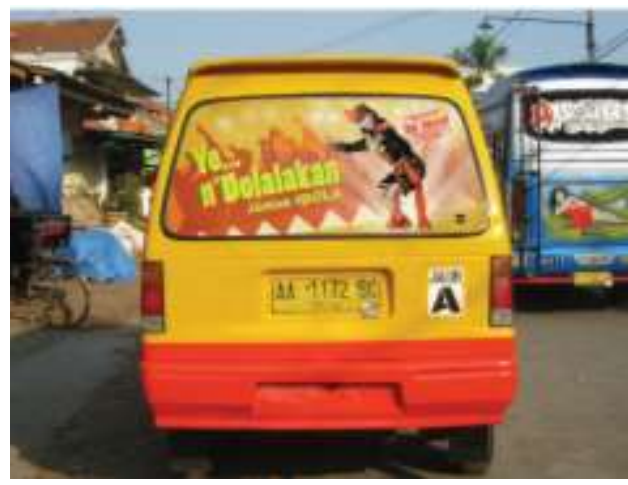

Gambar 10. Stiker angkot dengan desain Dolalak

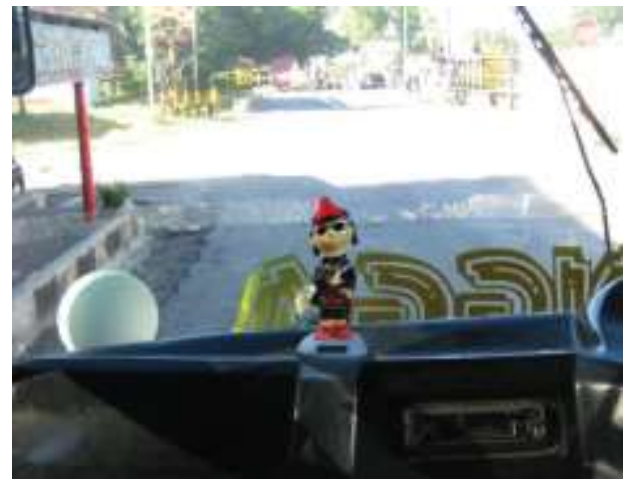

Gambar 11. Action figure dengan karakter penari Dolalak sebagai media pajangan

\section{KESIMPULAN}

Brand bukan sekedar sebuah nama, bukan juga sekedar logo atau simbol. Brand merupakan cermin nilai yang diberikan kepada khalayak baik berupa fisik maupun non fisik dari suatu entitas yang dapat membedakan dirinya dengan yang lain. Pembentukan brand daerah bukanlah hal yang mudah. Mengingat harus ada potensi unik yang bisa ditonjolkan oleh suatu daerah. Kabupaten Purworejo menetapkan
Dolalak sebagai ikon kesenian berdasarkan pertimbangan bahwa kesenian Dolalak merupakan kesenian aseli dari kabupaten Purworejo, memiliki keunikan dan menjadi kesenian yang populer di masyarakat Purworejo. Adanya kecintaan dan rasa memiliki dari masyarakat Purworejo membuat kesenian Dolalak bertahan hingga saat ini. Berbagai upaya telah dilakukan oleh pemerintah daerah kabupaten Purworejo dalam membangun brand Dolalak agar semakin besar dan dikenal oleh masyarakat luas, diantaranya melalui keikutsertaannya dalam berbagai event seni budaya yang diselenggarakan di berbagai kabupaten/kota di luar Purworejo, penyelenggarakan event pertunjukan Dolalak secara rutin, membuat desa wisata seni budaya Dolalak sebagai center point wisatawan, serta membuat logo branding yang dapat diaplikasikan keberbagai media sebagai identitas branding dari kabupaten Purworejo.

Aktivitas branding lain yang sudah dilakukan adalah dengan mengalih wahanakan tari Dolalak ke dalam berbagai media komunikasi visual. Akan tetapi hasil alih wahana yang dilakukan terkesan masih sebatas memindahkan gambar/foto ikon penari Dolalak. Karakteristik kesenian Dolalak yang memiliki gerakan tarian yang dinamis tidak terlihat/kurang dirasakan oleh pemirsanya, untuk itu disarankan kepada desainer grafis sebagai perancang desain visual untuk kebutuhan branding Dolalak perlu memahami terlebih dahulu apa yang menjadi konvensi dari tari Dolalak sehingga keputusan penggunaan/pemilihan gambar ikon penari Dolalak untuk kebutuhan komunikasi visual tepat, menguatkan pesan komunikasi yang akan disampaikan serta dapat mencirikan kesenian Dolalak Purworejo. 
Penggunaan media komunikasi visual dalam aktivitas branding Dolalak Purworejo masih menggunakan media konvensional yang dari segi pembiayaan relatif mahal namun jangkauannya sempit bahkan terkesan menghabiskan anggaran. Untuk itu, disarankan agar meninjau kembali keputusan terkait dengan strategi pemilihan media yang digunakan, jika memang terkendala dalam pembiayaan belanja media, maka dapat menggunakan jenis media lain yang tidak berbayar atau bahkan bisa memberikan tambahan pendapatan bagi pemerintah daerah. Contohnya seperti penggunaan sosial media yang terbukti efektif dan efisien karena memiliki jangkauan yang luas dan tidak berbayar. Seperti pembuatan desain platform stiker yang diperjualbelikan pada jenis komunikasi media sosial. Akan tetapi juga diperlukan keaktifan dari pengelola sosial media tersebut untuk menyampaikan informasi yang berkelanjutan serta aktif memandu jalannya diskusi antar anggota agar pesan komunikasi dapat tersampaikan dengan baik sehingga tujuan dari branding kabupaten Purworejo dapat tercapai.

Hal lain yang menarik dari kesenian Dolalak adalah persebaran kelompok Dolalak di wilayah Purworejo yang selanjutnya melahirkan penggayaan Mlaranan, Kaligesingan dan Pesisiran. Disarankan bagi peneliti lain, terutama yang berlatar belakang seni pertunjukan untuk mengkaji lebih lanjut seperti apa bentuk penggayaan kesenian Dolalak gaya Mlaranan, Kaligesingan dan Pesisiran, serta apa yang menjadi ciri/pembeda dari setiap penggayaan tersebut sehingga dapat memperkaya khasanah pengetahuan bagi masyarakat. Khususnya untuk landasan konsep pembangunan branding kabupaten Purworejo yang lebih baik lagi. 


\section{DAFTAR PUSTAKA}

[1] Ida, Rachmah. Metode Penelitian Studi Media dan Kajian Budaya, Jakarta: Prenada Media Group, 2014.

[2] Kasilo, Djito. Komunikasi Cinta, Menembus G-Spot Konsumen Indonesia, Jakarta: KPG (Kepustakaan Populer Gramedia), 2008.

[3] Prihartini, Nanik Sri. Dolalak: Tari Tradisi Masyarakat Purworejo, Surakarta: ISI Press Solo, 2007.

[4] Prihartini, Nanik Sri. Perkembangan Kesenian Dolalak Di Kabupaten Purworejo Jawa Tengah Tahun 1968 - 1999 (Sebuah Kajian Bentuk, Fungsi, dan Makna), Denpasar: Program Pascasarjana Universitas Udayana, 2000.

[5] Susanto A.B \& Himawan Wijanarko. Power Branding, Membangun Brand yang Legendaris, Bandung: Mizan, 2004.

[6] ------------, Deskripsi Kesenian Dolalak, Departemen Pendidikan dan Kebudayaan Kantor Wilayah Jawa Tengah. Semarang: Laporan Proyek Pembinaan Kesenian Jawa Tengah, 1992/1993.

[7] Swasty, Wirania. Branding, Memahami dan Merancang Strategi Merek, Bandung: PT. Remaja Rosdakarya, 2016.

\section{Wawancara:}

[1] Bambang Jati, 55 th. Bappeda kabupaten Purworejo. Wawancara 9 Oktober 2016, di Kantor Bappeda Kabupaten Purworejo.

[2] Jono, 54 th. Ketua kelompok Dolalak Budi Santoso, Kaligesing, Purworejo. Tanggal 21 Oktober 2016, di Desa Kaliharjo, Kaligesing, Kabupaten Purworejo.

[3] Untariningsih, SE. 56 th. Pamong Budaya, Dinas Pariwisata dan Kebudayaan Kabupaten Purworejo, Pada tanggal 23 Oktober 2016, di Kantor Dinas Pariwisata dan Kebudayaan Kabupaten Purworejo. 